\title{
Supramolecular crosslinks in mussel-inspired tissue adhesives
}

Diederik W. R. Balkenende* ${ }^{1}$, Sally M. Winkler*1,2, Yiran Li ${ }^{1}$, Phillip B. Messersmith ${ }^{1,3 * *}$

${ }^{1}$ Departments of Bioengineering and Materials Science and Engineering, University of California Berkeley, Berkeley, CA 94720-1760, USA

${ }^{2}$ University of California, Berkeley-University of California, San Francisco Graduate Program in Bioengineering, Berkeley, CA 94720, USA

${ }^{3}$ Materials Sciences Division, Lawrence Berkeley National Laboratory, Berkeley, CA 94720, USA

*Indicates equal contribution

**Correspondence to philm@berkeley.edu

SUPPORTING INFORMATION 


\section{Materials \& Methods}

Unless indicated otherwise, all chemicals and anhydrous solvents were obtained from Sigma Aldrich and used as received. All other non-anhydrous solvents were purchased from Macron Chemicals and used as received. Films of polycarbonate (PC) and Teflon were purchased from McMaster Carr.

\section{Characterization}

$N M R$

${ }^{1} \mathrm{H}-\mathrm{NMR}(400 \mathrm{MHz})$ spectra were recorded on a $400 \mathrm{MHz}$ Bruker Avance spectrometer in $\mathrm{CDCl}_{3}$ or DMSO-d6. ${ }^{1} \mathrm{H}$ NMR spectra were referenced against the signal for residual $\mathrm{CHCl}_{3}$ at $7.26 \mathrm{ppm}$ or DMSO at $2.50 \mathrm{ppm}$.

$G P C$

Gel Permeation Chromatography was performed on a Viscotek GPC Max equipped with Agilent Technologies PLgel $5 \mu \mathrm{m}$ Mixed-C columns in THF and calibrated on polystyrene standards.

Compression Molding

Compression molding was performed on a custom-made compression molder at $2000 \mathrm{psi}$ and $80^{\circ} \mathrm{C}$ for $1 \mathrm{~min}$ unless noted otherwise.

Photography

All photos were recorded on an Apple iPhone.

Tensile and shear adhesion tests

Tensile tests and shear adhesion tests were performed on an Instron 3345 tensile tester equipped with a $50 \mathrm{~N}$ load cell. Raw data from shear adhesion or tensile tests were processed using 
Bluehill 3 software. The elastic modulus was determined as the slope of the initial 5\% strain from the stress strain curves. The adhesion strength (in $\mathrm{kPa}$ ) was calculated as the maximum force divided by the overlapped area (as measured with a digital caliper).

\section{Data processing}

All raw data has been processed using Originlab or Microsoft Excel and statistical significance $(p<0.05)$ was determined using Students t-test.

\section{Differential scanning calorimetry}

Differential scanning calorimetry (DSC) measurements were performed using a MettlerToledo instrument operating at a heating/cooling rate of $10{ }^{\circ} \mathrm{C} \mathrm{min}{ }^{-1}$ with a range from -100 to 200 ${ }^{\circ} \mathrm{C}$ under an atmosphere of $\mathrm{N}_{2}$. Data from the second heating cycle are reported unless indicated otherwise.

Atomic force microscopy (AFM) imaging

AFM imaging experiments were carried out on a commercial AFM (JPK Nanowizard 3 Ultra) in QI mode. A silicon cantilever (ScanAsyst Fluid+, Bruker) with typical tip radii of $\sim 2 \mathrm{~nm}$ and resonance frequencies of $\sim 150 \mathrm{kHz}$ was used for imaging. Before AFM imaging experiments, polymer film was compression molded at onto a silicon wafer at $80{ }^{\circ} \mathrm{C}$ for less than 10 s. The polymer film on the wafer was then glued to a small petri dish. The petri dish was filled with 2-3 $\mathrm{ml}$ of PBS. AFM imaging was conducted after $30 \mathrm{~min}$ of equilibration. The image data and elastic modulus were analyzed using JPK data processing software.

\section{Synthetic methods}

General polymerization procedure (Polymer 6). Radical inhibitors were removed from commercial monomers by passage through activated basic alumina. DMA, 2-(6- 
isocyanatohexylaminocarbonylamino)-6-methyl-4[1H]pyrimidinone, and UPy methacrylate (UPy-MA; (ureido-4-pyrimidinone)-hexyl-amide-ethylmethacrylate) were synthesized as previously reported. ${ }^{1-3}$ An oven dried Schlenk flask equipped with a magnetic stirring bar was charged with UPy-MA (891 mg, $2.11 \mathrm{mmol}$ ), DMA (932 mg, $4.21 \mathrm{mmol}$ ), 2-ethylhexyl methacrylate (2.83 ml, $1.26 \mathrm{mmol})$, OEG20-MA (950 $\left.\mathrm{g} \mathrm{mol}^{-1}, 4.00 \mathrm{~g}, 4.21 \mathrm{mmol}\right)$, AIBN (17 mg, $0.11 \mathrm{mmol})$ and anhydrous DMF $(20 \mathrm{~mL})$. The flask was sealed with a rubber septum and four freeze-pump-thaw cycles were performed after which the Schlenk was backfilled with nitrogen. The reaction mixture was heated to $80{ }^{\circ} \mathrm{C}$ for 5 hours and allowed to cool to room temperature. The crude mixture was precipitated into ice cold ether $(350 \mathrm{~mL})$ and additionally reprecipitated 2 times from a DCM/methanol mixture $(8: 2,30 \mathrm{~mL})$ into ice cold ether $(350 \mathrm{~mL})$. All volatiles were removed in vacuo for 36 hours to obtain a semi-clear elastic polymer. Colorless films (thickness $=$ $200 \mu \mathrm{m})$ were prepared by compression molding between sheets of PTFE at $80^{\circ} \mathrm{C}, 2000$ psi for 1 min. We found that during polymerizations, only about half of the DMA in the reaction gets incorporated into the polymer; therefore, DMA feed amounts were doubled for all polymerizations. ${ }^{1} \mathrm{H}$ NMR $\left(400 \mathrm{MHz}, \mathrm{CDCl}_{3}\right) \delta 13.18,11.88,10.16,6.84,6.61,5.89,4.11,3.85$, $3.84,3.68,3.23,2.70,2.28,2.07,1.33,0.93 . \mathrm{GPC}(\mathrm{RI}) M_{\mathrm{n}}=42.6 \mathrm{~kg} / \mathrm{mol}$; polydispersity index, $\mathrm{PDI}=1.4$

Polymers 1-5, 7-9. The same procedure was as in 6 (above) was followed, with varying monomer compositions. Any changes are noted below.

Polymer 1. Reactants: UPy-MA (600 mg, $1.42 \mathrm{mmol}$ ), DMA (627 mg, $2.83 \mathrm{mmol})$, butyl methacrylate (1.41 g, $9.92 \mathrm{mmol})$, AIBN $(16.5 \mathrm{mg}, 0.14 \mathrm{mmol})$ and DMF $(20 \mathrm{~mL})$. Product: The general polymerization procedure was used to yield Polymer $\mathbf{1}$ as brittle and light orange 
transparent solid. ${ }^{1} \mathrm{H}$ NMR $\left(400 \mathrm{MHz}, \mathrm{CDCl}_{3}\right) \delta 13.19,11.91,10.17,6.84,6.79,6.65,5.88,4.36$, $3.98,3.30,3.28,2.77,2.27,1.67-0.90 . \mathrm{GPC}(\mathrm{RI}) M_{\mathrm{n}}=10.5 \mathrm{~kg} / \mathrm{mol}$; polydispersity index, $\mathrm{PDI}=$ 1.9.

Polymer 2. Reactants: UPy-MA (600 mg, 1.42 mmol), DMA (630 mg, 2.83 mmol), OEG9MA (500 $\left.\mathrm{g} \mathrm{mol}^{-1}, 4.96 \mathrm{~g}, 9.92 \mathrm{mmol}\right)$, AIBN (17 mg, $\left.0.15 \mathrm{mmol}\right)$ and anhydrous DMF (10 mL). Product: The general polymerization procedure yielded Polymer $\mathbf{2}$ as transparent elastomeric solid. Due to the low glass transition and resulting stickiness of this material, it was necessary after compression molding to cool the polymer film and PTFE sheets to $-80{ }^{\circ} \mathrm{C}$ to remove the PTFE sheets. ${ }^{1} \mathrm{H}$ NMR $\left(400 \mathrm{MHz}, \mathrm{CDCl}_{3}\right) \delta 13.14,11.87,10.12,6.83,6.81,6.76,6.59,5.88,4.11,4.10$, $3.67,3.58,3.41,2.73,2.28,1.53,1.39,1.28,1.02,0.91$. GPC (RI) $M_{\mathrm{n}}=34.3 \mathrm{~kg} / \mathrm{mol}$; polydispersity index, $\mathrm{PDI}=3.2$.

Polymer 3. Reactants: UPy-MA (300 mg, $0.71 \mathrm{mmol})$, DMA (314 mg, $1.42 \mathrm{mmol})$, butyl methacrylate (282 mg, $1.98 \mathrm{mmol})$, OEG3-MA (200 $\left.\mathrm{g} \mathrm{mol}^{-1}, 596 \mathrm{mg}, 2.98 \mathrm{mmol}\right)$, AIBN (8mg, $0.07 \mathrm{mmol})$ and DMF $(10 \mathrm{~mL})$. Products: The general polymerization procedure was used to yield Polymer 3 as transparent hard solid. ${ }^{1} \mathrm{H}$ NMR (400 MHz, $\left.\mathrm{CDCl}_{3}\right) \delta 13.14,11.87,10.14,6.85,6.78$, $6.77,6.61,5.88,4.13,3.97,3.68,3.59,3.42,3.27,2.72,2.27,1.98,1.63,1.42,0.98,0.89$. GPC (RI) $M_{\mathrm{n}}=5.9 \mathrm{~kg} / \mathrm{mol}$; polydispersity index, $\mathrm{PDI}=2.3$.

Polymer 4. Reactants: UPy-MA (446 mg, 1.05 mmol), DMA (465 mg, 2.10 mmol), butyl methacrylate (484 mg, $3.40 \mathrm{mmol})$, OEG9-MA (500 $\left.\mathrm{g} \mathrm{mol}^{-1}, 1.98 \mathrm{~g}, 3.97 \mathrm{mmol}\right)$, AIBN (12 mg, $0.11 \mathrm{mmol})$, and anhydrous DMF $(10 \mathrm{~mL})$. Products: The general polymerization procedure was 
used to yield Polymer 4 as transparent elastomeric solid. ${ }^{1} \mathrm{H}$ NMR $\left(400 \mathrm{MHz}, \mathrm{CDCl}_{3}\right) \delta 13.17$, $11.87,10.11,6.85,6.78,6.61,5.89,4.13,3.97,3.68,3.41,2.70,2.29,2.28,2.07,2.03,1.64,1.63$, $1.42,1.29,0.98,0.92,0.91,0.91,0.90,0.89 . \mathrm{GPC}(\mathrm{RI}) M_{\mathrm{n}}=23.6 \mathrm{~kg} / \mathrm{mol}$; polydispersity index, $\mathrm{PDI}=3.4$.

Polymer 5. Reactants: UPy-MA (200 mg, $0.47 \mathrm{mmol})$, DMA (209 mg, $0.95 \mathrm{mmol})$, butyl methacrylate (382 mg, $2.69 \mathrm{mmol})$, OEG20-MA (950 g mol$\left.{ }^{-1}, 591 \mathrm{mg}, 0.62 \mathrm{mmol}\right)$, AIBN (8 mg, $47 \mu \mathrm{mol})$ and DMF (10 mL). Product: The general polymerization procedure was used to yield Polymer 5 as elastomeric solid. ${ }^{1} \mathrm{H}$ NMR $\left(400 \mathrm{MHz}, \mathrm{CDCl}_{3}\right) \delta 13.16,11.88,10.15,6.85,6.78$, $6.61,5.88,3.97,3.68,3.60,3.41,3.27,2.71,1.98,1.64,1.42,0.98,0.89 . \mathrm{GPC}(\mathrm{RI}) M_{\mathrm{n}}=9.7$ $\mathrm{kg} / \mathrm{mol}$; polydispersity index, $\mathrm{PDI}=2.3$.

Polymer 7. Reactants: UPy-MA (600 mg, $1.41 \mathrm{mmol})$, DMA (627 mg, $2.83 \mathrm{mmol})$, lauryl methacrylate $(2.40 \mathrm{ml}, 8.49 \mathrm{mmol})$, OEG20-MA (950 $\left.\mathrm{g} \mathrm{mol}^{-1}, 2.89 \mathrm{~g}, 3.04 \mathrm{mmol}\right)$, AIBN (12 mg, $0.07 \mathrm{mmol})$ and DMF (10 mL). Product: The general polymerization procedure was used to yield Polymer 7 as transparent elastomeric solid. ${ }^{1} \mathrm{H} \mathrm{NMR}\left(400 \mathrm{MHz}, \mathrm{CDCl}_{3}\right) \delta 13.17,11.87,10.14$, $6.82,6.77,6.59,5.88,3.94,3.66,3.59,3.41,3.23,2.73,2.26,1.63,1.29,0.91$. Reliable PDI and molecular weight measurements could not be completed as polymer showed interaction with the GPC column.

Polymer 8. Reactants: UPy-MA (287 mg, $0.68 \mathrm{mmol})$, 2-ethylhexyl methacrylate $(1.13 \mathrm{ml}$,

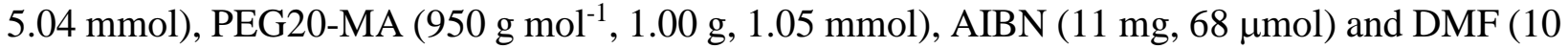
$\mathrm{mL}$ ). Product: The general polymerization procedure was used to yield Polymer $\mathbf{8}$ as white 
elastomeric solid. ${ }^{1} \mathrm{H}$ NMR (400 MHz, $\left.\mathrm{CDCl}_{3}\right) \delta 13.17,11.91,10.20,5.87,4.11,3.86,3.68,3.42$, $3.28,2.29,1.78,1.58,1.40,1.33,1.06,0.93$. GPC (RI) $M_{\mathrm{n}}=33.3 \mathrm{~kg} / \mathrm{mol}$; polydispersity index, $\mathrm{PDI}=1.3$.

Polymer 9. Reactants: DMA (337 mg, $1.52 \mathrm{mmol})$, 2-ethylhexyl methacrylate $(1.13 \mathrm{ml}$, $5.03 \mathrm{mmol})$, PEG20-MA (950 $\left.\mathrm{g} \mathrm{mol}^{-1}, 1.00 \mathrm{~g}, 1.05 \mathrm{mmol}\right)$, AIBN (13 mg, $\left.76 \mu \mathrm{mol}\right)$ and DMF (10 $\mathrm{mL}$ ). Product: The general polymerization procedure was used to yield Polymer $\mathbf{9}$ as transparent elastomeric solid. Due to the low glass transition and resulting stickiness of this material it was necessary after compression molding to cool the polymer film and PTFE sheets to $-80{ }^{\circ} \mathrm{C}$ to remove the PTFE sheets. ${ }^{1} \mathrm{H}$ NMR $\left(400 \mathrm{MHz}, \mathrm{CDCl}_{3}\right) \delta$ 6.85, 6.77, 6.63, 4.11, 3.85, 3.68, 3.60, 3.42, 2.76, $1.89,1.58,1.41,1.33,1.06,0.93 . \mathrm{GPC}(\mathrm{RI}) M_{\mathrm{n}}=53.8 \mathrm{~kg} / \mathrm{mol}$; polydispersity index, $\mathrm{PDI}=1.6$.

\section{Swelling of polymer films.}

PBS powder concentrate (Fisher) and DI water were used to prepare 1X PBS solution. Dry and films of polymer (between 5 and $10 \mathrm{mg}$ each, $\mathrm{n}=3$ ) were submerged into PBS (20 mL) and the sample mass was monitored at pre-set intervals. Prior to weighing the samples, surface water was removed using a laboratory tissue (Kimwipe). The swelling ratio (in wt\%) was calculated by subtracting the original dry mass from the swollen mass and dividing by the original dry mass.

\section{Tissue adhesion studies.}

Lap shear tissue adhesion studies were conducted according to ASTM-2255-05 (Figure S1). In short, large polycarbonate (PC) films were cut into rectangular struts $(6 \times 1 \mathrm{~cm})$ to which tissue and adhesives could be attached for mounting into the Instron. Untreated and freshly 
harvested bovine pericardium was purchased from Animal Technologies Inc. (Tyler, TX, USA), shipped on wet ice, frozen in liquid nitrogen, and stored at $-80{ }^{\circ} \mathrm{C}$. Prior to use, frozen tissue was thawed in excess PBS for at least 60 min. Freshly thawed and moist bovine pericardium was adhered on the rough (and fatty) side to the textured side of the PC strut with Loctite all-purpose liquid super glue. Subsequently, the tissue was trimmed around the edges to obtain struts with rectangular strip of bovine pericardium (Figure S1a). As prepared struts were temporarily stored in PBS solution prior to use. Polymer films ( $200 \mu \mathrm{m}$ thickness) were cut into $1 \mathrm{x} 1 \mathrm{~cm}$ squares and adhered to polycarbonate struts using super glue. In cases in which $\mathrm{NaIO}_{4}$ was used as oxidant, a piece of cotton wool soaked with $\mathrm{NaIO}_{4}$ solution $(0.1 \mathrm{M})$ was brushed on the adhesive polymer

film for $5 \mathrm{~s}$ and excess solution was removed via gentle blotting with a Kimwipe. Lap joints were prepared by overlapping $(1 \mathrm{~cm}$ overlap) a strut with bovine pericardium with a strut with a polymer adhesive film and hand pressed together for $5 \mathrm{sec}$ (Figure S1f). Samples were submerged into PBS solution at $37{ }^{\circ} \mathrm{C}$ for $1 \mathrm{~h}$ either using a mini binder clip (Office Depot brand) as clamping device or a 200g brass weight for each sample (Figure S1c). After incubation, lap joints were removed from solution and subjected to a shear tensile test (strain rate $=5 \mathrm{~mm} \mathrm{~min}^{-1}$ ) until failure. The shear adhesion strength (in $\mathrm{kPa}$ ) was calculated as the maximum load divided by the initial overlapped area.

\section{Determination of failure mode after shear adhesion tests.}

To determine the mode of failure, both the tissue strut and the strut with the adhesive patch were subjected to Arnow's stain after shear adhesion tests. The lap joints were submerged into a $\mathrm{HCl}$ solution $(0.5 \mathrm{M}, 5 \mathrm{~mL})$ for $5 \mathrm{~min}$, then transferred into a nitrating solution $\left(\mathrm{NaNO}_{2}, 0.1 \mathrm{~g} \mathrm{ml}^{-1}\right.$; $\left.\mathrm{NaMoO}_{4}, 0.1 \mathrm{~g} \mathrm{ml}^{-1}\right)$ for $5 \mathrm{~min}$ and finally transferred into a $\mathrm{NaOH}$ solution $(1 \mathrm{M}, 5 \mathrm{~mL})$ for $5 \mathrm{~min}$. 
Images were recorded immediately after the staining on a white paper background. Cohesive failure was concluded when reddish color was observed on the tissue surface, indicating that the adhesive patch had fractured, leaving polymer residue (and therefore Arnow-stainable catechol) bound to the tissue surface. Adhesive failure was indicated when the tissue only showed a lightyellow color due to the presence of phenolic amino acids and the absence of adhesive patch residue. This assay is able to detect relatively small amounts of catechol residue that are otherwise invisible to the naked eye and appears to be independent of film thickness.

\section{Burst tests.}

A piece of bovine pericardium was secured to a large piece of polycarbonate with super glue (Loctite liquid all-purpose); the edges were glued securely, and an area of approximately 4 sq $\mathrm{cm}$ was left unglued in the center. A $3 \mathrm{~mm}$ hole was punched through center of the tissue and PC using a biopsy punch (Figure S8a). A round film of adhesive was shortly hand-pressed onto the pericardium, and incubated under a $200 \mathrm{~g}$ brass weight for $1 \mathrm{~h}$ in $\mathrm{PBS}$ at $37{ }^{\circ} \mathrm{C}$. Then the PC/tissue/adhesive patch setup was mounted into the custom-made burst device, with a fluid-tight seal forming between the device's gaskets and the PC (Figure S8b). The device was inflated with PBS using an Orion Sage syringe pump at $10 \mathrm{ml} \mathrm{min}^{-1}$ until the adhesive polymer patch failed (Figure S8c). The pressure at adhesive failure was measured in-line using an Additel 680 pressure gauge.

Adhesive patches with a polycaprolactone (PCL) backing were prepared by separately preparing thin $(100 \mu \mathrm{m})$ films of adhesive polymer and of PCL (both at $80{ }^{\circ} \mathrm{C}, 2000 \mathrm{psi}, 1 \mathrm{~min}$ ) and then shortly compression molded in a sandwiched fashion at 500 psi for 15 s to attach the 2 films together and form a PCL-backed adhesive patch. 


\section{Cytocompatibility studies.}

NIH 3T3 and CCD-32sk cells were cultured to sub-confluence in 96 well plates. Polymer films were conditioned in cell culture media (DMEM with $10 \%$ fetal bovine serum, $1 \%$ penicillin/streptomycin, and $10 \mathrm{mM}$ HEPES) at a known concentration for $24 \mathrm{~h}$ at $37^{\circ} \mathrm{C}$. Then, $100 \mu \mathrm{L}$ of conditioned media was applied to cells. After growing with exposure to conditioned media for 24 hours, cells were cultured an additional $3 \mathrm{~h}$ in serum-free, neutral red supplemented media, following the protocol in ISO 10993-5. Control samples included cells with untreated media and cells cultured with media supplemented with sodium laurel sulfate $\left(0.2 \mathrm{mg} \mathrm{ml}^{-1}\right.$, negative control). After neutral red staining, cells were rinsed with warm PBS, and lysed in a solution of $50 \%$ ethanol, $40 \%$ distilled water, and $10 \%$ acetic acid. Absorbance at $540 \mathrm{~nm}$ was measured on a plate reader and all wells were compared with untreated cells to calculate relative viability. 
a

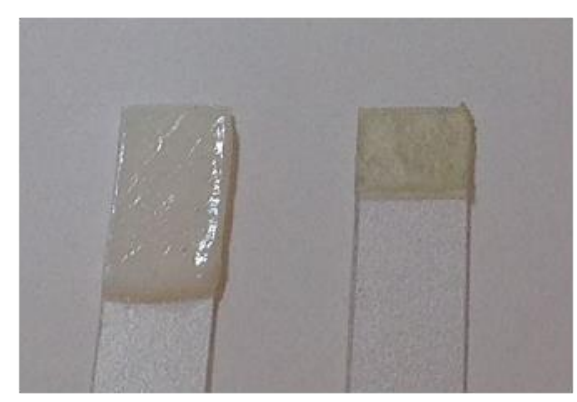

C

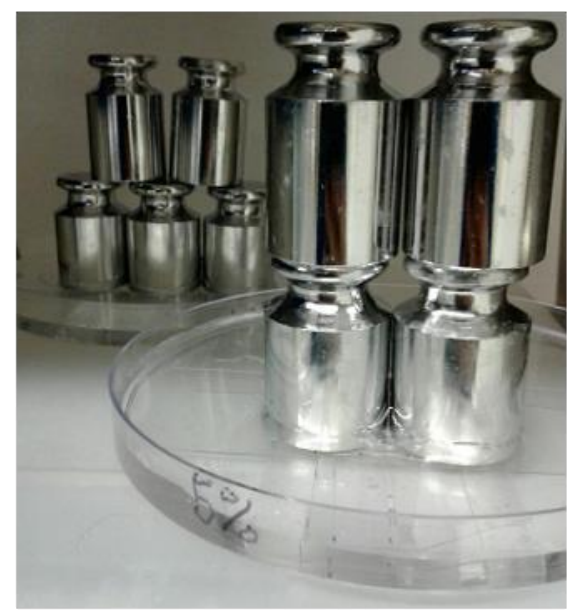

b

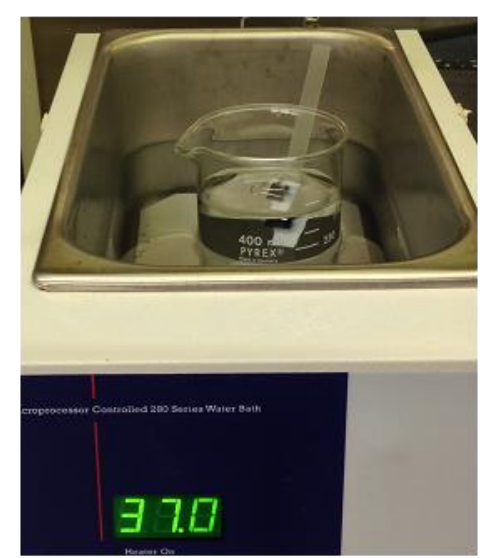

d

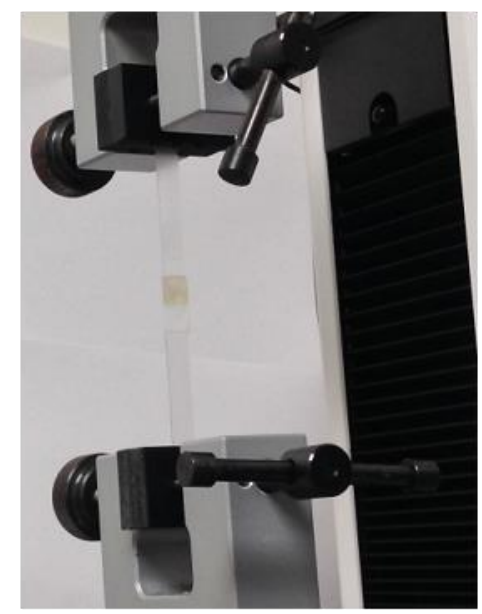

e

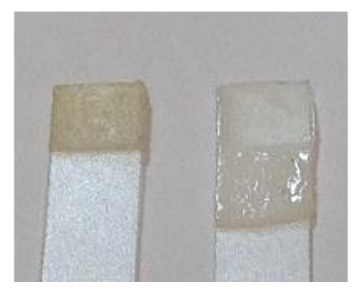

f

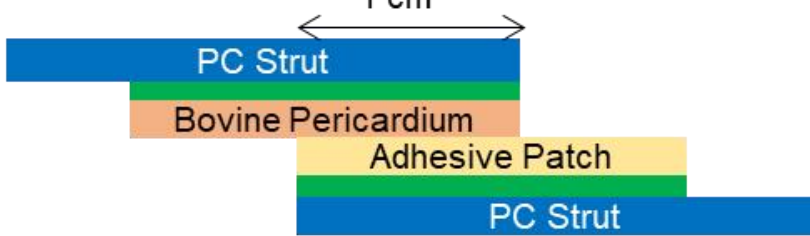

Figure S1. Method used for tissue lap shear adhesion tests. a, Struts with bovine pericardium (left) and adhesive polymer (right) prior to formation of a lap joint. $\mathbf{b}$. Incubation of a lap joint held together by a binder clip in PBS in a $37^{\circ} \mathrm{C}$ bath. c, Incubation of a set of lap joints pressed together with one $200 \mathrm{~g}$ brass weight for each sample in PBS in an incubator at $37{ }^{\circ} \mathrm{C}$. d, Shear adhesion tensile test setup on an Instron mechanical tester. e, Image of a failed lap joint before Arnow's staining. $\mathbf{f}$, Schematic of a cross-section of a lap joint of bovine pericardium tissue and adhesive patch samples, each adhered to a polycarbonate (PC) strut with super glue (green). 


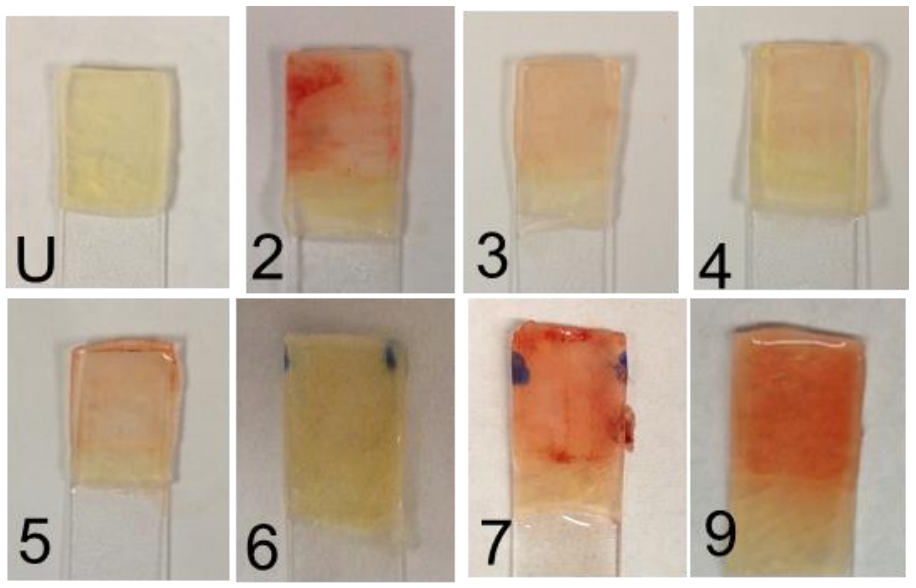

Figure S2. Tissue from failed lap joints after Arnow's staining. Failed lap joints were stained with Arnow's stain. Unstained (U) tissue is shown along with tissue that had been in lap joints with the adhesive polymer patches (numbered). Data not shown for patches $\mathbf{1}$ and $\mathbf{8}$ due to low adhesion (1) and lack of catechols (8). Blue marks seen in $\mathbf{6}$ and $\mathbf{7}$ are Sharpie marks leftover from cutting the PC struts and do not influence samples or staining.

a
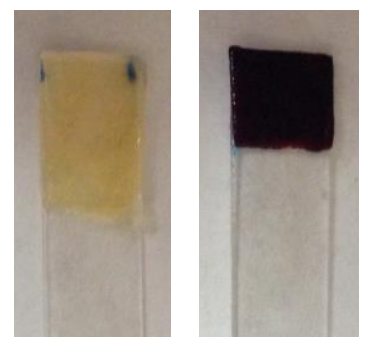

C

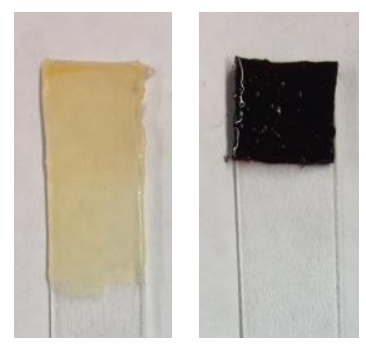

b

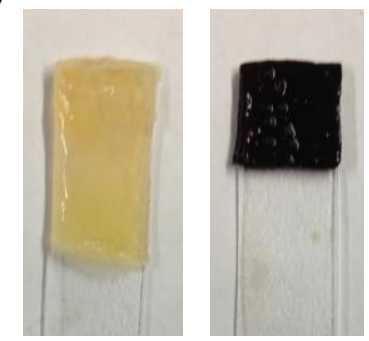

Figure S3. Arnow's stain of lap joints after shear adhesion tests of Polymer 6 using different methods of incubation. During incubation for $1 \mathrm{~h}$ in $37^{\circ} \mathrm{C}$ PBS, lap joints were (a) clamped with binder clips, (b) compressed with $200 \mathrm{~g}$ brass weights, and (c) compressed with $200 \mathrm{~g}$ brass weights after brushing adhesive polymer surface with $\mathrm{NaIO}_{4}(0.1 \mathrm{M})$ for $5 \mathrm{~s}$ before forming the lap joint with the tissue. Note that all samples exhibit cohesive failure (no reddish residue on tissue surface). 


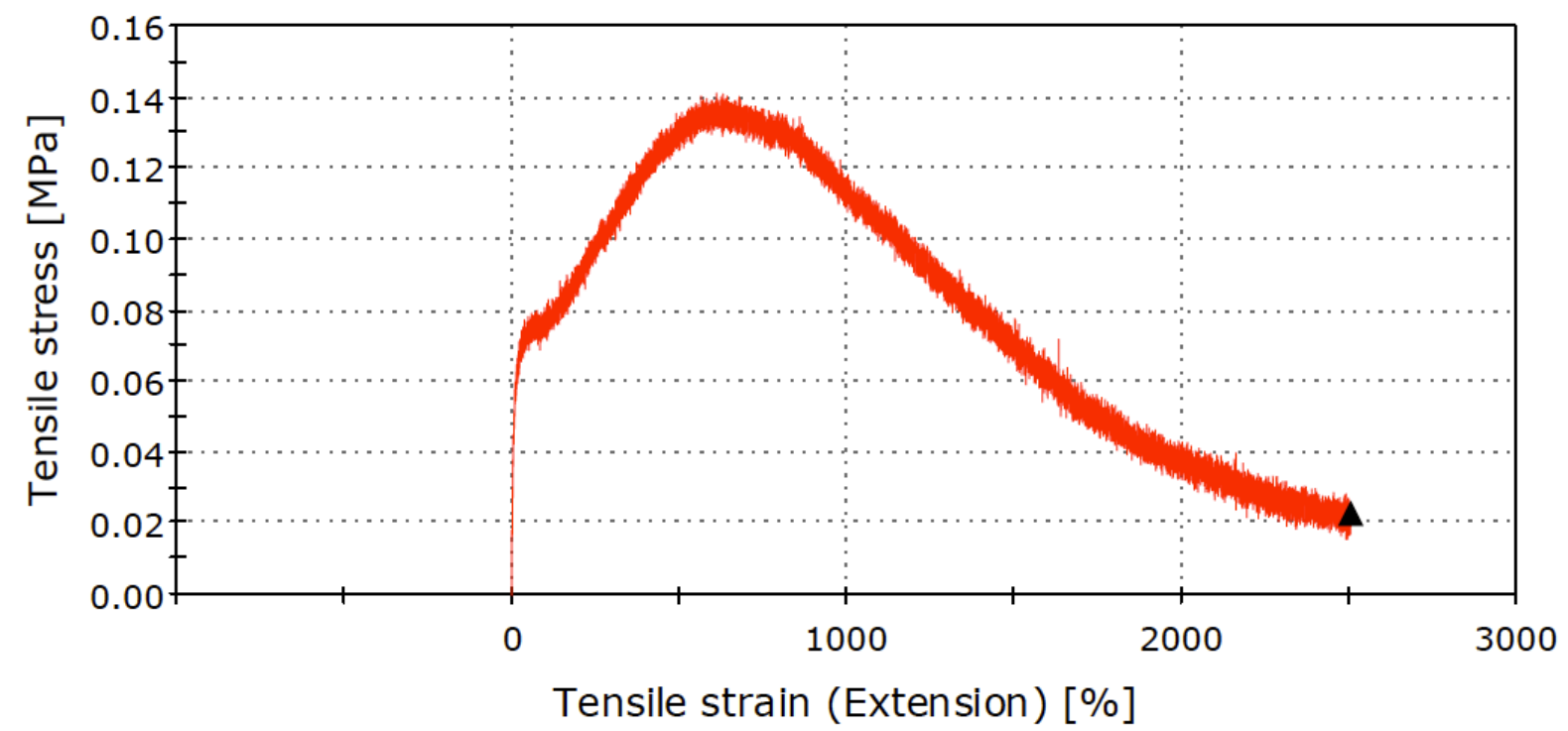

Figure S4. Representative tensile test of Polymer 6 in the dry state $\left(5 \% \mathrm{~min}^{-1}\right)$. Triangle indicates last collected datapoint, at the limits of the instrument.

a

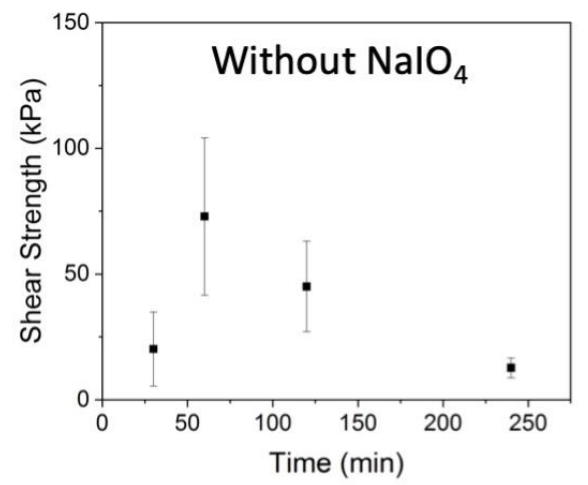

b

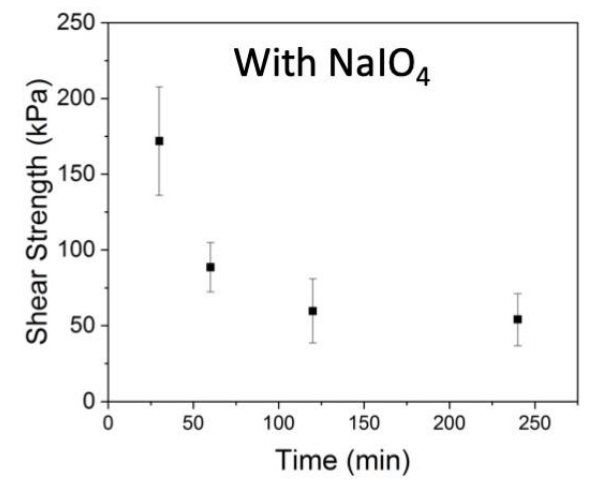

Figure S5. Time dependent tissue adhesion experiments with and without oxidative crosslinker. Without the use of $\mathrm{NaIO}_{4}$, the formation of an adhesive interface with a tissue surface is limited by the autoxidation of DMA, and swelling may lead to breaking of interfacial bonds. To test the influence of autoxidation and swelling, we studied the time dependence of tissue adhesion strength of Polymer $\mathbf{6}$ in neat and oxidized samples. a, For the neat sample, an initial increase in adhesive strength was followed by a decrease in adhesive strength (incubated with $200 \mathrm{~g}$ weights). This result may indicate that the adhesive interface is strained and ruptures as the material swells. b. Time dependent tissue adhesion strength of Polymer 6 that was incubated with $200 \mathrm{~g}$ weights and brushed with $\mathrm{NaIO}_{4}(\mathrm{c}=0.1 \mathrm{M}, 5 \mathrm{~s})$ show a high shear strength of $171.9 \pm 35.8 \mathrm{kPa}$ after 30 min followed by a steady decease to $54.2 \pm 17.2 \mathrm{kPa}$ after 4 hours. Both of the time dependent tissue adhesion tests show a decrease in adhesive strength as a function of time. However, upon oxidizing the surface, fast formation of interfacial and cohesive crosslinks may be essential to withstand interfacial stress caused by swelling. 


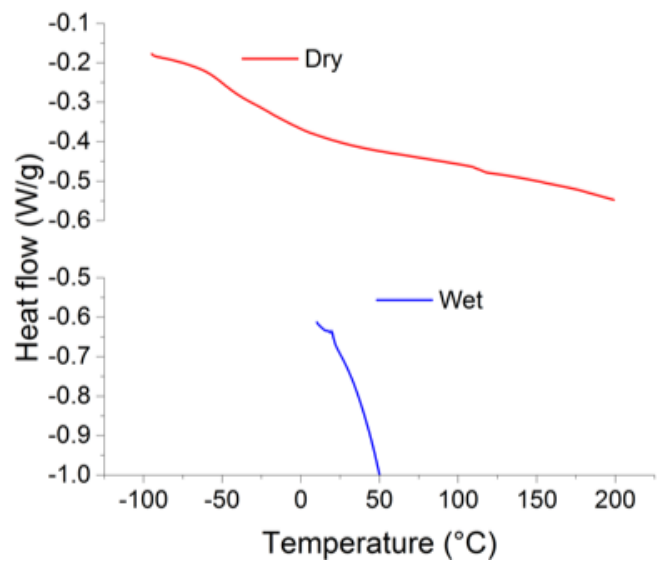

Figure S6. Differential scanning calorimetry (DSC) traces of the second heating of Polymer 6 in the dry (-) and swollen (-) state at a heating rate of $10{ }^{\circ} \mathrm{C} \mathrm{min}^{-1}$ under a $\mathrm{N}_{2}$ atmosphere.

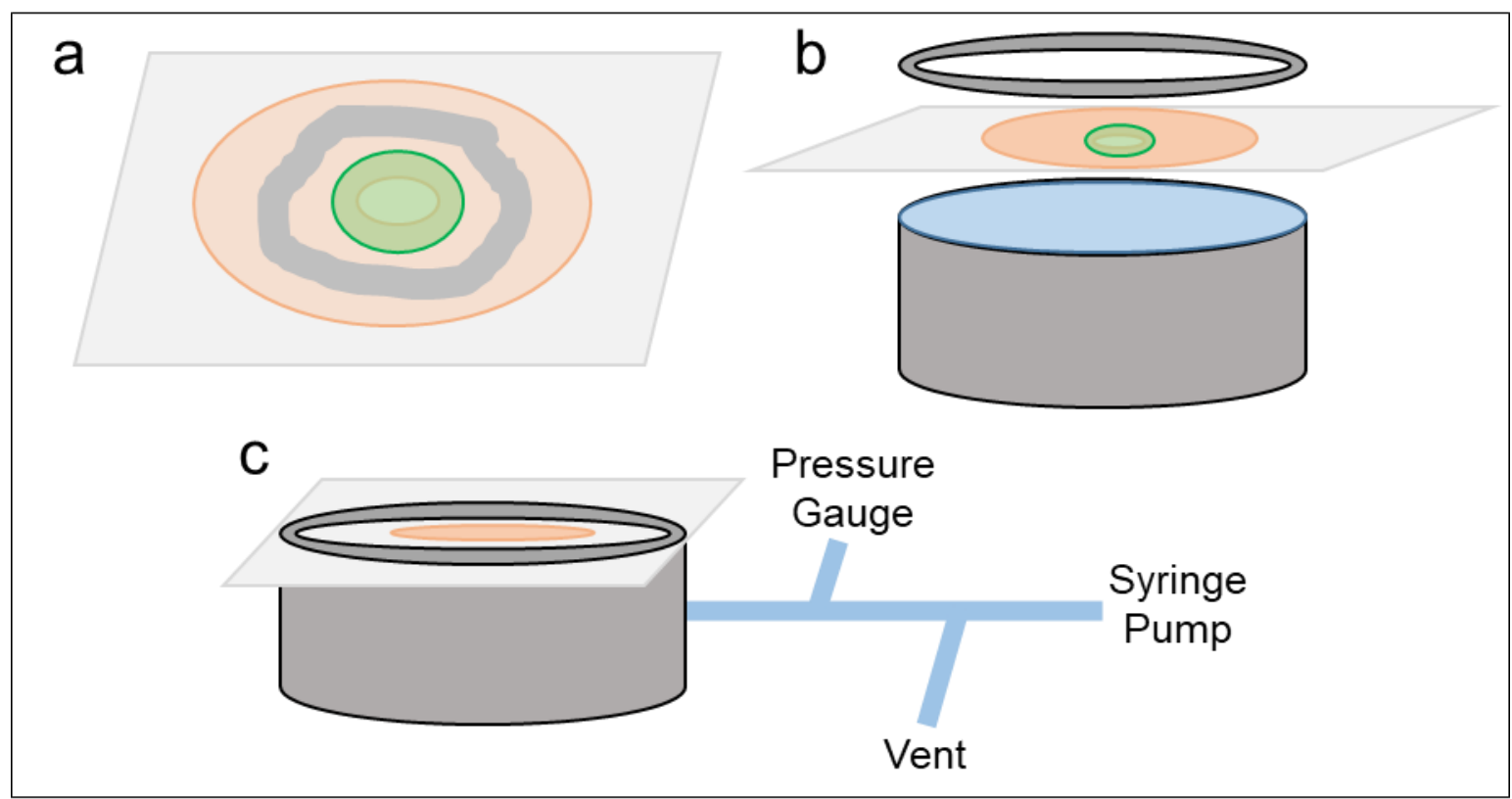

Figure S7. Schematic of burst device chamber. a, Bovine pericardium (orange) affixed to polycarbonate (grey) with superglue. A $3 \mathrm{~mm}$ hole is punched through the tissue and strut, and an adhesive patch (green) adheres to the tissue, covering the hole. b, Loading of the polycarbonatetissue-patch into the fluid-filled burst device chamber. c, Diagram showing burst chamber inflation and measurement setup; the vent (liquid inlet) is closed during operation. 


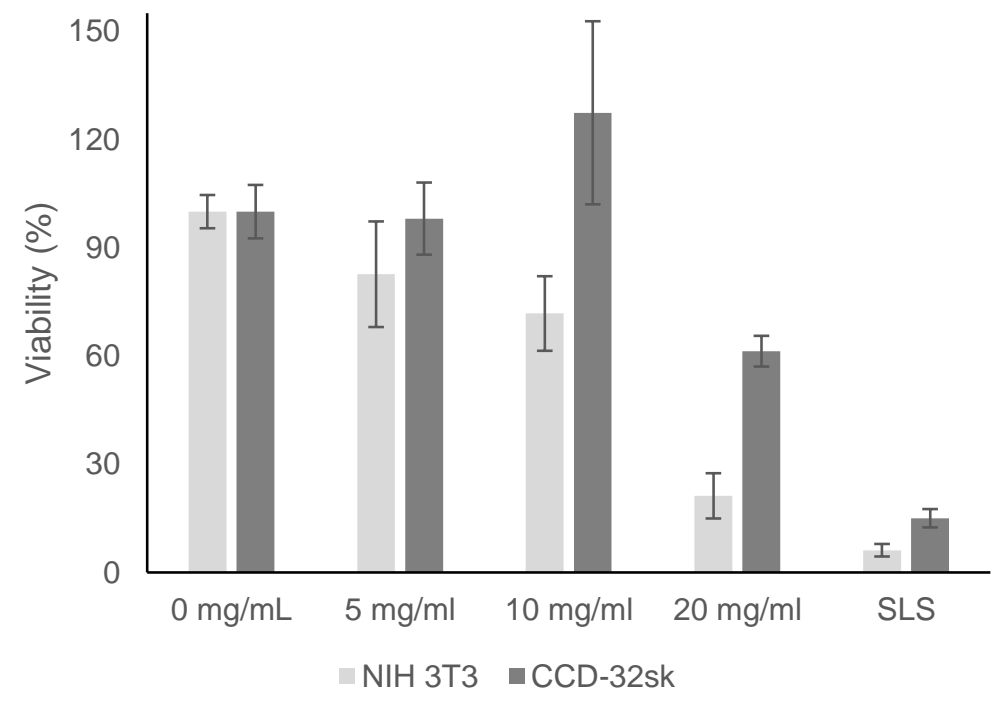

Figure S8. Dose-dependent cytocompatibility of Polymer 6. NIH 3T3 and CCD-32sk cells were grown for $24 \mathrm{~h}$ in media conditioned with Polymer 6 . Dose-dependent cell viability was seen. SLS $=$ sodium lauryl sulfate. Mean \pm SD of $n \geq 4$ samples/condition. 

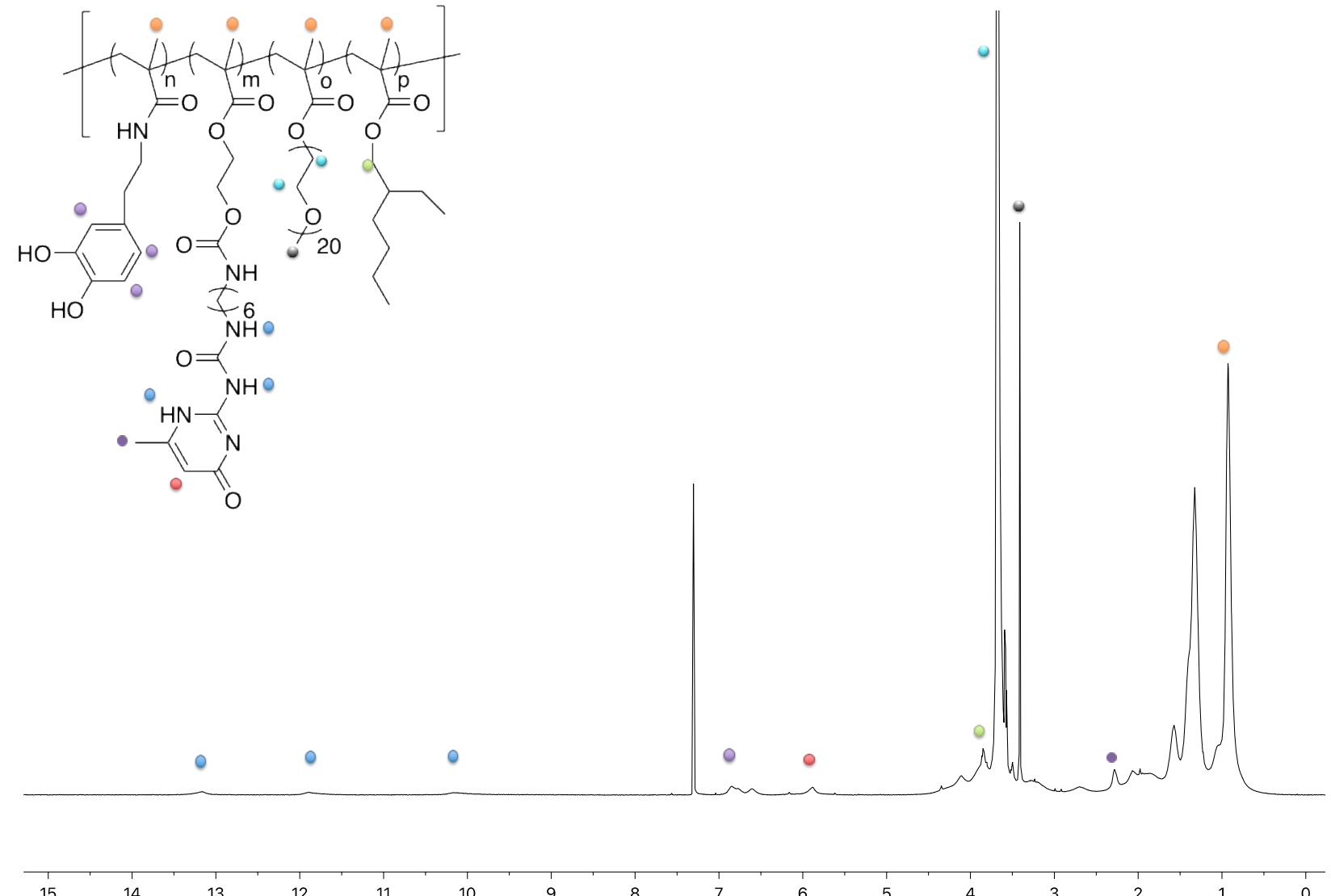

$14 \quad 13$

Figure S9. ${ }^{1}$ H-NMR spectrum of Polymer 6. 

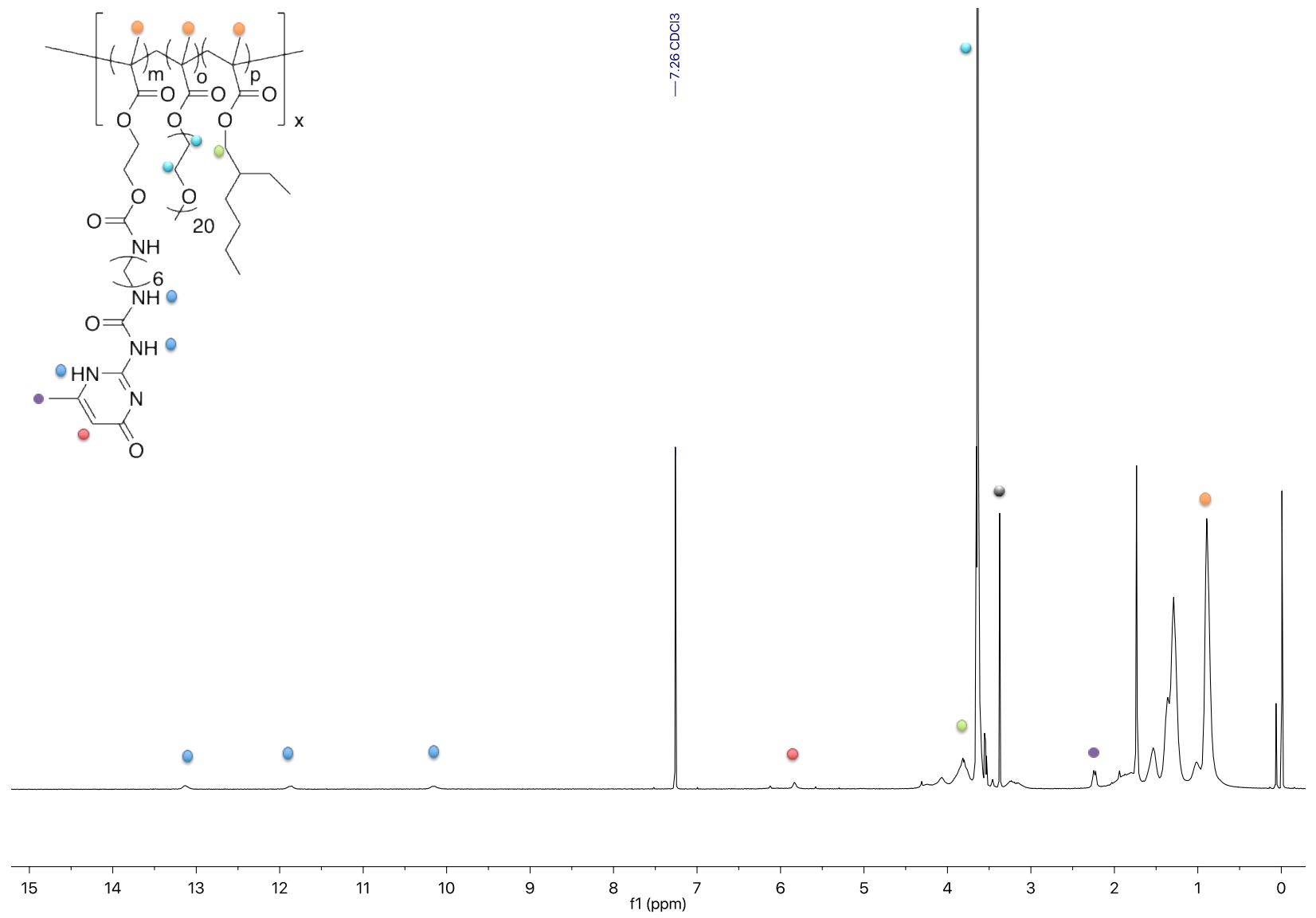

Figure S10. ${ }^{1}$ H-NMR spectrum of Polymer 8 

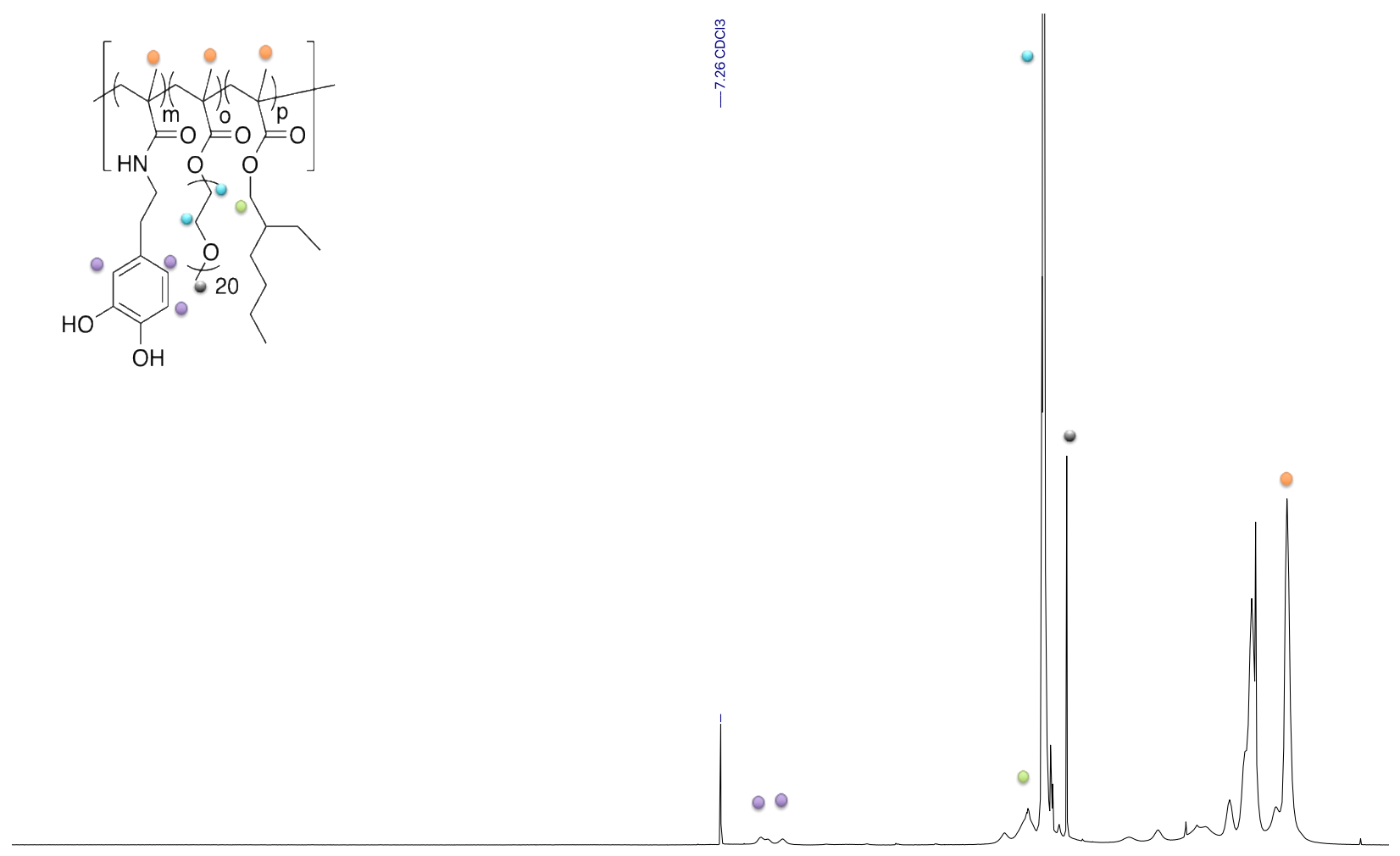

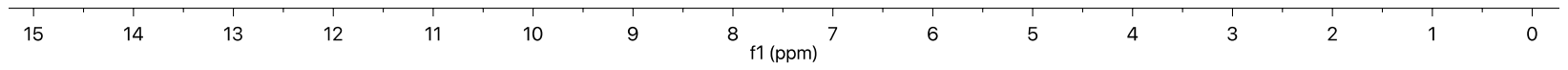

\section{Figure S11. ${ }^{1} \mathrm{H}-\mathrm{NMR}$ spectrum of Polymer 9}

\section{References}

1. Wu, H.; Sariola, V.; Zhu, C.; Zhao, J.; Sitti, M.; Bettinger, C. J., Transfer Printing of Metallic Microstructures on Adhesion-Promoting Hydrogel Substrates. Adv. Mater. 2015, 27 (22), 3398-3404.

2. $\quad$ Keizer, H. M.; van Kessel, R.; Sijbesma, R. P.; Meijer, E. W., Scale-up of the synthesis of ureidopyrimidinone functionalized telechelic poly(ethylenebutylene). Polymer 2003, 44 (19), 5505-5511.

3. Berda, E. B.; Foster, E. J.; Meijer, E. W., Toward Controlling Folding in Synthetic Polymers: Fabricating and Characterizing Supramolecular Single-Chain Nanoparticles. Macromolecules 2010, 43 (3), 1430-1437. 